\section{A narrativa do impeachment de Dilma Rousseff nas páginas dos jornais brasileiros}

[The narrative of Dilma Rousseff's impeachment in the pages of Brazilian newspapers]

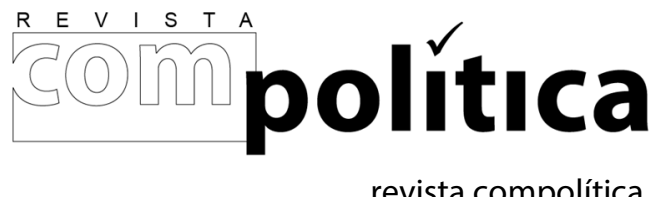

revista compolítica 2018, vol. 8(2)

compolitica.org/revista ISSN: 2236-4781

DOI: 10.21878/compolitica.2018.8.2.151 O Open Access Journal

\section{Carla Rizzotto}

Universidade Federal do Paraná

[Federal University of Paraná]

\section{Daniela Drummond}

Universidade Federal do Paraná [Federal University of Paraná]

\author{
Diego Antonelli \\ Universidade Federal do Paraná \\ [Federal University of Paraná]

\section{Paulo Ferracioli} \\ Universidade Federal do Paraná \\ [Federal University of Paraná]
}

\begin{abstract}
Resumo
O processo de impeachment da presidenta Dilma Rousseff é uma questão, sem dúvida, multifacetada. A construção narrativa e a utilização de "ganchos" visuais são mecanismos jornalísticos úteis para enfrentar o desafio que se coloca diante da produção das notícias de temas com tal característica. Assim, esta pesquisa pretende responder como se deu a construção narrativa da destituição de Dilma Rousseff por parte de dois dos mais importantes jornais brasileiros, a Folha de S. Paulo e O Globo. Tal análise leva em consideração o grau de narratividade, o gênero narrativo e os atores identificados em seus respectivos papéis. Foram analisadas 997 notícias veiculadas entre os dias 2 de dezembro de 2015, data em que o pedido de impeachment foi aceito pelo então presidente da Câmara dos Deputados, Eduardo Cunha, e 13 de maio de 2016, data que marcou o afastamento da presidenta Dilma após o Senado Federal aprovar a instauração do processo de impeachment.
\end{abstract}

Palavras-chave: impeachment, análise narrativa, jornais.

\begin{abstract}
The impeachment process of president Dilma Rousseff is undoubtedly multifaceted. The narrative construction and the use of visual "hooks" is a journalistic mechanism useful to face the challenge that comes during the production of the news of subjects with such characteristic. Thus, this research intends to investigate the narrative construction of the dismissal of Dilma Rousseff by two of the most important Brazilian newspapers, Folha de S. Paulo and O Globo. This analysis takes into account the degree of narrativity, the narrative genre and the actors identified in their respective roles. A total of 997 news were published between December 2, 2015, the date on which the request for impeachment was accepted by the then president of Chamber of Congressmen of Brazil, Eduardo Cunha, and May 13, 2016.
\end{abstract}

Keywords: impeachment, narrative analysis, newspapers. 


\section{A narrativa do impeachment de Dilma Rousseff nas páginas dos jornais brasileiros}

Carla RIZZOTTO

Daniela DRUMMOND

Diego ANTONELLI

Paulo FERRACIOLI

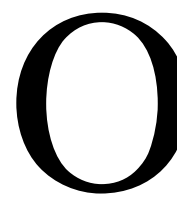

processo de impeachment da presidenta Dilma Rousseff (PT) ocorreu entre dezembro de 2015 e agosto de 2016. O pedido de impedimento de Dilma a acusava de ter cometido as chamadas "pedaladas fiscais", operações contábeis do Tesouro Nacional que visam atrasar de forma proposital o repasse de dinheiro para bancos (públicos e também privados) e autarquias (como o INSS - Instituto Nacional do Seguro Social), o que foi interpretado como crime de responsabilidade. O então presidente da Câmara dos Deputados, Eduardo Cunha (PMDB), acatou o processo que então teve início em 2 de dezembro de 2015. Em 17 de abril de 2016 os deputados autorizam a instauração do processo de impeachment com uma votação de 367 votos a favor e 137 votos contra, em uma sessão que foi transmitida em tempo real por quase todos os canais de televisão, rádio e também pela internet.

Após a aprovação do processo pela Câmara, ele seguiu para o Senado Federal, onde a admissibilidade do pedido foi votada no dia 12 de maio de 2016, com 55 votos a favor e 22 contra. O senador Antonio Anastasia, do PSDB, partido da oposição ao governo Dilma, foi o relator do processo. Dilma foi afastada por até 180 dias e o vice-presidente, Michel Temer (PMDB) assumiu interinamente a Presidência da República. Na votação final do impeachment, que ocorreu no dia 31 de agosto, Dilma foi definitivamente afastada, com 61 votos a favor e 20 contra. Apesar da cassação, ela manteve a elegibilidade.

A cobertura jornalística destes acontecimentos foi alvo de diversas críticas, que afirmavam que os vieses tinham como objetivo direcionar a interpretação dos leitores, tanto contra, como a favor do impedimento da presidenta. O que pode ser explicado por Gunther (1992) ao afirmar que, quando as posições das pessoas diante de algumas questões estão muito polarizadas, a confiança na cobertura dos meios de comunicação tende a diminuir. 
Pesquisas acadêmicas já mostravam uma cobertura negativa da imprensa em relação ao Partido dos Trabalhadores (PT), partido de Dilma Rousseff e do ex-presidente Luís Inácio Lula da Silva, muito antes do início desse processo. Aldé, Mendes e Figueiredo (2007) e Mundim (2012) mostraram que tanto nas eleições de 2002 quanto na de 2006 a cobertura do jornalismo impresso foi negativa para Lula. No escândalo de corrupção conhecido como Mensalão, ainda no primeiro governo Lula, o então presidente e seu governo foram severamente criticados e diretamente ligados à corrupção por veículos midiáticos (Prior; Guazina; Araújo; 2015; Miguel; Coutinho, 2007), em uma postura que reforçava a necessidade de se corrigir um "desvio" através da punição de atores envolvidos no escândalo.

Mais recentemente, Feres Júnior e Sassara (2016) mostraram que houve uma cobertura mais negativa contra Dilma durante as eleições de 2014 nos veículos do Grupo Globo, o maior grupo de comunicação da América Latina. A pesquisa concluiu que "o viés antiDilma observado na cobertura do pleito de 2014 não deve ser atribuído ao comportamento watchdog, mas, sim, à reiteração do comportamento antipetista já fartamente identificado pela tradição de estudos de mídia e eleições em nosso país" (Feres Júnior; Sassara, 2016, p. 57).

Especificamente acerca do processo de impeachment Guazina e Santos (2017) discutiram a cobertura jornalística do jornal Folha de S. Paulo através da análise das capas das edições, tendo chegado à conclusão de que não houve uma pluralidade de vozes e que o jornal reafirmou o discurso da crise. As autoras perceberam que o tema impeachment já aparece na capa do jornal na semana seguinte a reeleição de Dilma Rousseff. Em relação aos temas, apontaram que a economia e/ou crise econômica, justamente a causa apontada como justificativa do impeachment por aqueles que eram favoráveis à saída de Dilma, foi abordada em apenas 2,3\% dos textos. (Guazina; Santos, 2017).

A construção da imagem pública de Dilma Rousseff nas revistas semanais Veja e Carta Capital concluiu que a ela é tratada como brava, inflexível e, ao mesmo tempo, "pulso firme" e resistente. Os distintos pontos de vista apresentam a heterogeneidade de sentidos que caracterizam Dilma. Verificou-se também que há a presença de argumentos econômicos nas críticas à ex-presidenta, demonstrando como o momento político do impeachment influenciou na construção da sua imagem pública. Outro elemento 
importante verificado foi a questão de gênero, a análise mostrou posicionamentos machistas nas matérias das revistas (Lima; Simões, 2017). Marques, Mont'alverne e Mitozo (2017), em estudo sobre editoriais verificaram que as empresas jornalísticas optaram por posicionamentos explícitos e, em sua maioria, favoráveis ao impeachment.

Tendo em vista que a mídia sofre influências que direcionam a cobertura dos acontecimentos políticos e que essa mesma cobertura intervém na formação da opinião pública (GOMES, 2007), a pesquisa macro da qual este artigo é resultado busca agregar outra perspectiva para a discussão sobre os acontecimentos políticos que marcaram o ano de 2016, através da utilização da análise multimodal, que envolve o enquadramento noticioso, bem como a construção narrativa e imagética (Wozniak et al, 2014).

A pesquisa realizada pelo Grupo de Pesquisa em Comunicação e Participação Política (COMPA) da Universidade Federal do Paraná (UFPR) teve como objetivo analisar a cobertura do impeachment por três dos mais importantes jornais brasileiros: Folha de $S$. Paulo, O Globo e O Estado de S. Paulo, durante todo o processo - desde o início do trâmite, em 2 de dezembro de 2015, até o afastamento definitivo da presidenta, em 31 de agosto de $2016^{1}$.

A análise de enquadramento multimodal é vantajosa, pois permite, de um lado, verificar detalhes que passam despercebidos pela análise de enquadramento clássica e, de outro, apontar incongruências da cobertura jornalística (Rizzotto; Prudencio; Sampaio, 2017).

Neste artigo, todavia, focamos em apenas um dos três aspectos - a construção narrativa da cobertura, adotando como corpus as notícias veiculadas nas editorias de política ou equivalente dos jornais Folha de S. Paulo e $O$ Globo, durante a tramitação do processo na Câmara dos Deputados e no Senado Federal, ou seja, de 2 de dezembro de 2015 a 13 de maio de 2016. Foram excluídos do corpus entrevistas e artigos de opinião, bem como notícias que não fossem acompanhadas de imagens - ainda que elas não tenham sido analisadas neste artigo específico - resultando em 997 notícias.

\footnotetext{
${ }^{1}$ A codificação dos dados completos da pesquisa pode ser encontrada em: https://bdc.c3sl.ufpr.br/handle/123456789/26.
} 


\section{A narrativa jornalística: uma versão da história}

Partimos da premissa que explica que as narrativas são dispositivos argumentativos usados nos jogos de linguagem. Como afirma Motta (2005, p.2), a forma como contamos os acontecimentos na narrativa está impregnada pela narratividade que é a "qualidade de descrever algo enunciando uma sucessão de estados de transformação", ou seja, a narrativa traduz o conhecimento objetivo e subjetivo do mundo em relatos.

É importante salientar que as narrativas são recursos discursivos que os jornalistas utilizam socialmente de acordo com suas pretensões, além de serem formas de relações estabelecidas por causa da cultura, das condições sociais e hierarquias de poder. Partimos do pressuposto de que nenhuma narrativa é ingênua, assim, a análise busca compreender as estratégias do narrador. Toda narrativa gira em torno do conflito, e é essa expectativa em torno do desenlace das histórias que mantém as notícias nos jornais. A narrativa jornalística contém, na maioria das vezes, conotações dramáticas imediatas e negativas, que irrompem, desorganizam e transtornam (Motta, 2005).

Fazem parte dos dramas do jornalismo o inesperado, como exemplo, escândalos, golpes, crimes, rompimentos e quaisquer anormalidades. Além disso, em quase toda narrativa jornalística há sempre pelo menos dois lados em confronto. As personagens do texto jornalístico costumam ser fortemente individualizadas e transformam-se no eixo das histórias. É válido analisar como as notícias constroem personagens, conflitos, combates, heróis, vilões, mocinhos, bandidos, e como estabelecem punições e recompensas. Conforme Motta (2005, p.7) "não estamos fazendo uma análise da realidade histórica em si mesma. Nosso objeto é a versão, não a história”.

Na narrativa jornalística interessa como se constrói a imagem de um personagem e quais as ações dele no texto. $\mathrm{O}$ narrador define as marcas que pretende transmitir para seus leitores, entretanto o personagem do jornalismo está diretamente ligado com a pessoa da vida real, o que gera uma complexidade singular, uma vez que não se trata de personagem puramente ficcional. Uma das estratégias do narrador jornalístico é a de dar ares de realidade ao seu relato quando, na observação do mundo atual, o jornalista ancora seu relato 
no presente e busca antecipar o futuro, fazendo uma mediação simultaneamente linguística e temporal (Mesquita, 2002; Motta, 2005).

Motta (2005) afirma que o texto jornalístico também tem como característica ser fortemente determinado por um fundo ético ou moral. Os fatos selecionados da realidade são aqueles que transgridem algum preceito ético ou moral, alguma lei, algum consenso cultural. Segundo o autor, linguagem jornalística é dramática e a sua retórica é tão ampla e rica quanto a literária. Enfim, a análise da narrativa jornalística deve observar particularmente o "contrato cognitivo" implícito entre jornalistas (narradores) e audiência (narratário) em seu contexto operacional. Esse "contrato" segue as máximas da objetividade e da co-construção da "verdade dos fatos": o objetivo é co-construir a verdade, a "realidade objetiva" (Motta, 2005, p.13).

A literatura brasileira nessa área é extensa e produz constantes reflexões voltadas à análise da narrativa jornalística. A construção de uma cultura compartilhada de significados por parte dos veículos de comunicação já foi apontado como elemento impactante para a construção dos textos jornalísticos (Motta, Guazina, 2010). Houve avanços teóricos para se distanciar de possíveis acusações de relativismo, ao demonstrar que a construção das narrativas permite a ampliação dos horizontes de compreensão do leitor, mas sem determinar que não existam verdades universais (Teixeira, 2016). Foi possível, ainda, captar como a escolha das fontes e o foco preferencial em ações do que em declarações de personagens são características de textos que aprimoram os textos noticiosos (Magno, 2014).

Recente produção nacional tem demonstrado a amplitude dos estudos de narrativa: seja no que diz respeito aos gêneros analisados, como pesquisas voltadas à comparação entre textos opinativos ou informativos (Correia, 2017), seja na diversidade temática: análises sobre cobertura política hard news (Shuen, 2017; Kabuenge; Costa; Ferreira Junior, 2018), questões indígenas (Costa; Fernandes, 2018), e até mesmo discussões sobre a ocupação na Palestina (Silva; Mota, 2017). Em todos esses casos, os pesquisadores realizaram estudos sobre narrativa/narratologia dos principais jornais brasileiros e demonstraram as estratégias textuais utilizadas para destacar certos atores e construir negativamente a imagem de outros. 
Tendo em vista as características da narrativa jornalística acima descritas, nosso estudo leva em consideração o grau de narratividade, o gênero narrativo e os atores identificados em seus respectivos papéis, conforme proposto por Wozniak et al (2014). O grau de narratividade é medido com base na dramatização, emoção, personalização e ornamentação estilística. A análise do gênero narrativo é focada no tema geral da notícia (assuntos cotidianos, foco no personagem, história de sucesso, história de fracasso e conflito político/social); no tom utilizado (pessimista/negativo, otimista/positivo, neutro); e nos resultados alcançados (não se espera resultado, conflito resolvido, conflito não resolvido). Por fim, a análise da narrativa compreende a verificação dos papéis - vítima, herói e vilão - associados aos sujeitos representados nas notícias ${ }^{2}$.

\section{A narrativa do impeachment de Dilma Rousseff}

Conforme já exposto, o artigo se concentrou em um corpus de notícias publicadas entre 02 de dezembro de 2015 e 13 de maio de 2016, em dois jornais impressos brasileiros de alcance nacional, Folha de S. Paulo (FSP) e $O$ Globo (GLO) ${ }^{3}$. As notícias foram coletadas por meio dos sites dos acervos dos portais, que reproduzem a versão impressa, através da palavra-chave "impeachment". Essa busca rendeu 997 notícias, sendo 450 da FSP e 557 do GLO, cuja análise será exposta a seguir.

\section{Narratividade}

Inicialmente, a análise da narrativa busca elementos que indiquem o grau de narratividade de cada um dos textos, medido através da dramatização, da emoção, da personalização e da ornamentação estilística. Esses quatro elementos poderiam aparecer ou não nas matérias.

A dramatização apareceu num total de 316 matérias (o que representa 31,6\% do universo de matérias analisadas). Esse elemento esteve presente nos casos em que, ao invés de

2 O livro de códigos utilizado para a análise pode ser encontrado em: https://bdc.c3sl.ufpr.br/handle/123456789/27.

${ }^{3}$ A partir desse momento, os jornais serão citados pelas siglas. 
apresentar a informação seguindo a ordem hierárquica de importância - modelo jornalístico conhecido como pirâmide invertida -, a notícia apresentava uma história contada em ordem sequencial, com início, meio e fim. Na matéria "MBL distribui panfletos em feira livre de favela em SP" (FSP, 12/12/2015), por exemplo, o texto começa retratando a distribuição de panfletos por um bairro paulistano, fornecendo vários detalhes. A revelação de que se trata de integrantes do Movimento Brasil Livre (MBL) só aparece no terceiro parágrafo, o que contraria a tradição do lead, ou seja, de apresentar os aspectos mais importantes já no primeiro parágrafo do texto.

No texto "O sumiço do mais longevo ministro da Fazenda" (GLO, 01/05/2016), a dramatização também é marcante. Para construir um perfil do ex-ministro Guido Mantega, a notícia traz, de início, um episódio envolvendo Mantega e a ex-presidenta Dilma Rousseff em 2014, com o intuito de construir o personagem, sem qualquer preocupação em responder imediatamente às questões como o quê, quando, quem e onde.

A emoção apareceu em 316 (31,69\%) textos e está, por sua vez, relacionada aos sujeitos presentes na notícia. Uma vez que o estado emocional de um ou mais sujeitos tenha sido descrito, ela foi considerada existente. Para exemplificar tal situação, é possível citar o texto "Não tem pra onde correr" (GLO, 01/04/2016), que aborda comentários feitos pelo ministro do Supremo Tribunal Federal (STF) Luis Roberto Barroso. O jornal narrou que, em palestra dada a alunos, o juiz "lamentou ontem a falta de alternativa para comandar o país", proferindo a frase "Meu Deus do céu, essa é a nossa alternativa de poder". Já a matéria "Governistas querem constranger Temer a apoiar presidente" (FSP, 04/12/2015) traz trechos como "o mercado financeiro reagiu com euforia ao encaminhamento do processo de impeachment", o que também demonstra com clareza a existência do elemento emoção nesses textos.

A personalização diz respeito ao foco em alguns personagens e suas ações para o relato da reportagem. Essa característica estava presente em 507 notícias (50,85\% do total), em clara predominância sobre as outras três categorias analisadas em relação ao grau de narratividade. Na matéria "Só vou pedir que ela assine e sair", publicada pela FSP em 11/05/2016, por exemplo, o jornal se concentra na figura do senador Vicentinho Alves (PR), a quem coube a tarefa de notificar Dilma Rousseff de seu afastamento do cargo. 
O último item que ajuda a compor a narratividade do texto é a ornamentação estilística, ou seja, a utilização de vocabulário ou estruturas frasais que não sejam típicas do jornalismo quotidiano. Na matéria "Os versos do poeta profeta do Tietê", veiculada por GLO em 13/12/2015, é possível perceber que o jornalista usa elementos típicos da literatura para descrever as reações da população da cidade natal de Temer com a proximidade do impeachment. O trecho a seguir ilustra essa característica: "Como não relacionar os versos de "A carta" e "Tempo que passa", por exemplo, com o rompimento da aliança política com a presidente Dilma Rousseff no momento de maior crise do governo?".

O gráfico abaixo resume a presença das características citadas nos textos analisados, demonstrando, ainda, a divisão por periódico:

\section{Gráfico 1 - Grau de narratividade}

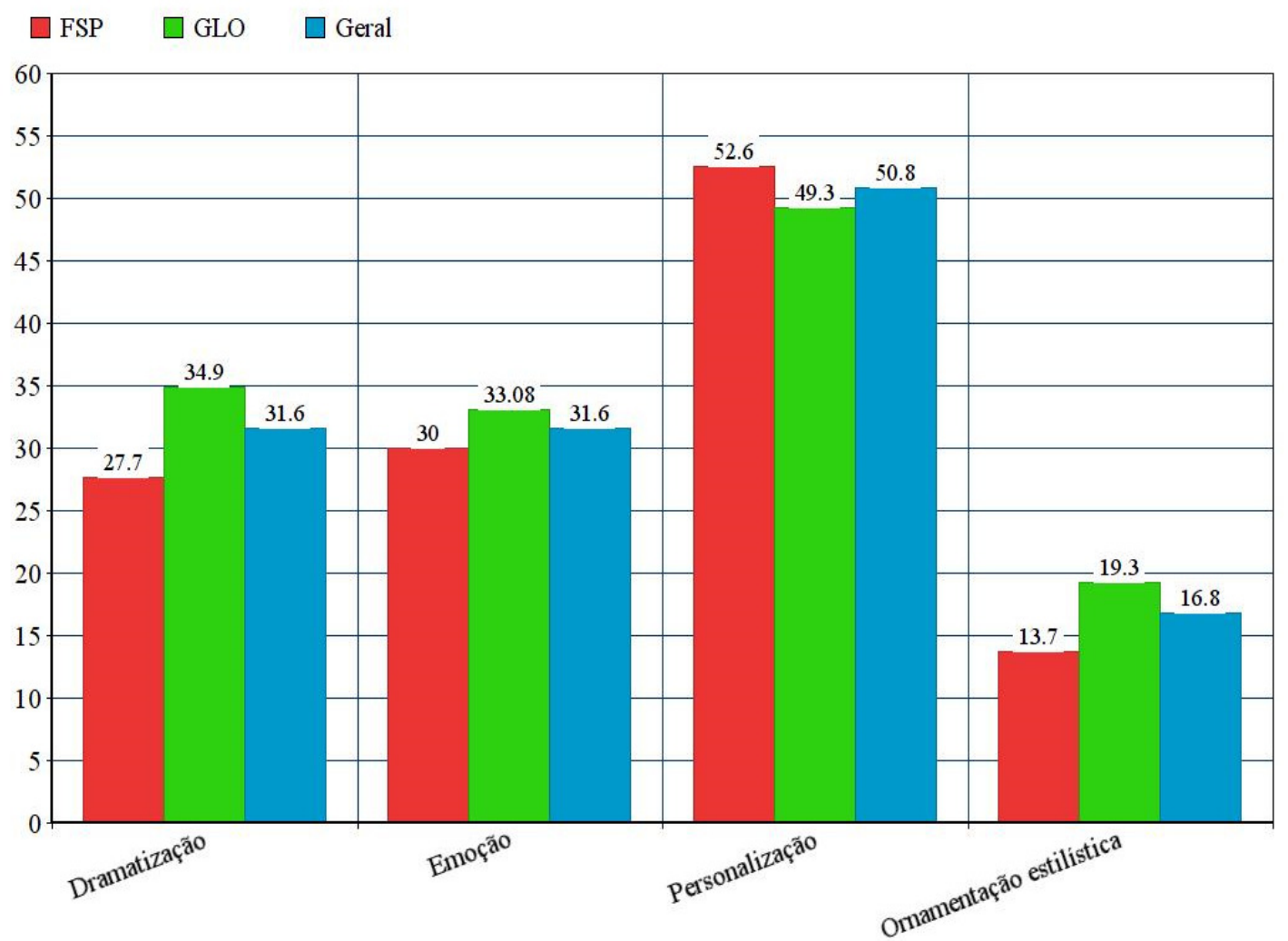

Fonte: COMPA/UFPR 
A diferença entre FSP e GLO não é tão significativa, mas o GLO apresenta uma utilização de estratégias narrativas levemente superior, com exceção da variável personalização, utilizada mais frequentemente pela FSP. A personalização ocorrida em cerca de metade do corpus demonstra que, ainda que o jornalismo brasileiro tradicionalmente se caracterize pela busca pela objetividade e, consequente, foco nos fatos mais do que em suas interpretações, na cobertura política tende a personalizá-la, instituindo no imaginário público uma percepção da política focada em seus agentes formais, ou seja, constrói a ideia de que política é somente o que é feito pelos representantes eleitos.

\section{Gênero Narrativo}

A análise de enquadramento narrativo que foi levada a cabo envolve também a classificação das notícias em tema, tom e resultados esperados. A variável tema apresentava cinco possibilidades: assuntos cotidianos (os acontecimentos são tratados como usuais ou burocráticos), foco no personagem (textos que privilegiam relatos e experiências de um protagonista), história de sucesso (triunfo do personagem), história de fracasso (fracasso do protagonista do texto) e conflito político-social (matéria foca no embate entre os personagens).

Dentre os textos analisados, assuntos cotidianos foi o tema predominante, com 404 textos. Eram matérias como "Temer vai chefiar órgão que formula política comercial”, publicada pela FSP em 12/05/16, que tratava do impeachment sem alarde, ressaltando, nesse caso, que Temer passaria a presidir e dar centralidade à Câmara de Comércio Exterior. Não há intenção do texto de aprofundar um debate sobre o tema, mas apenas de relatar o acontecimento de maneira usual, cotidiana.

Em segundo lugar, apareceram as notícias com foco no personagem (310 textos), seguido pelo conflito político-social (223 ocorrências). Na notícia "Presidente mergulha no varejo da política para salvar seu mandato" (FSP, 17/04/16), é possível perceber essa recorrência: o texto é centrado em descrever as atitudes de Dilma Rousseff para escapar do impeachment. Já o conflito político-social, que foi o terceiro tema mais recorrente, abordava as brigas entre os grupos pró e contra impeachment, como no texto "Oposição quer a renúncia da presidente" (GLO, 04/03/16). 
Os temas de história de fracasso e história de sucesso tiveram poucas aparições em comparação com as outras categorias, com 23 e 8 aparições, respectivamente. A abordagem do fracasso apareceu, por exemplo, no texto "Na despedida, afagos e melancolia" (GLO, 13/05/16), que retratava os bastidores do fim abrupto do governo Dilma Rousseff. O relato do sucesso, que foi o tema com menos aparições, esteve presente quando a votação na Câmara foi aprovada pelos deputados na noite do domingo, 17 de abril ("Resultado da votação é recebido com buzinaço e choro na Paulista”, FSP, 18/04/2016). O texto descreve a felicidade dos brasileiros que defendiam a saída da presidenta e se sentiram vitoriosos pelo fato de o número mínimo de 342 congressistas ter sido alcançado.

O gráfico 2, abaixo, demonstra a proporção de cada tema, apontando também a recorrência em cada veículo de comunicação:

\section{Gráfico 2 - Tema geral}

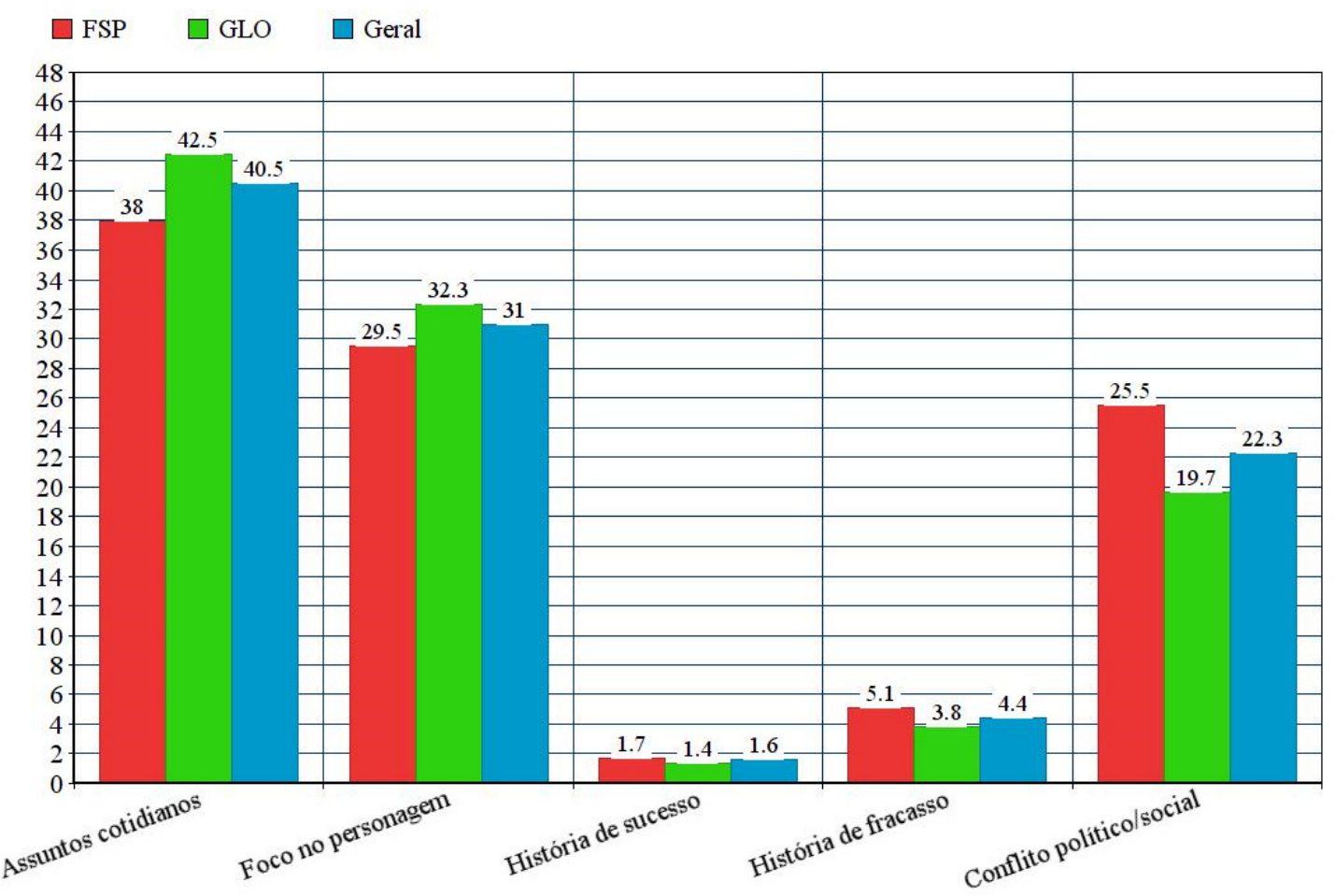

Fonte: COMPA/UFPR

Outra variável analisada foi o tom das matérias, que poderia ser positivo, negativo ou neutro. Os resultados demonstraram que houve uma predominância de tom neutro nos 
periódicos, com frequências bem parecidas. Na FSP, 61,33\% dos textos foram identificados como neutros (o que equivale a 276 matérias), enquanto no GLO a neutralidade foi a tônica de $62,34 \%$ dos textos (342 matérias). Um exemplo disso é a matéria "Renan ignora deputado, e impeachment vai a voto na 4 "a (FSP, 10/05/2016), que aborda a decisão do então presidente do Senado, Renan Calheiros, em manter a primeira votação do impeachment naquela casa do Congresso mesmo com a decisão do deputado Waldir Maranhão (então no PP) de anular a votação na Câmara. Não há um enfoque positivo ou negativo sobre a questão no texto, o que o caracteriza como neutro. $\mathrm{O}$ tom pessimista apareceu em segundo lugar, apresentando uma frequência em torno de $31 \%$, seja no conjunto dos jornais (313 matérias ao todo), seja em cada periódico avaliado separadamente (141 na FSP e 172 no GLO). No texto "Planalto teme debandada do PMBD após saída de ministro" (FSP, 05/12/15), é possível apreender esse tom negativo pelo receio do governo Dilma em perder o apoio do maior partido da base. Em terceiro e último lugar nessa variável, restou o tom otimista/positivo, que apareceu 67 vezes no conjunto geral. No início do processo do impeachment, a matéria "Levantamento indica que, hoje, Dilma tem margem confortável" (GLO, 04/12/15) utilizava esse tom para abordar a então ampla maioria de que a presidenta desfrutava no Senado. A seguir, o gráfico 3 ilustra todas as recorrências, com as frequências de cada tom nos jornais analisados. 


\section{Gráfico 3 - Tom utilizado}

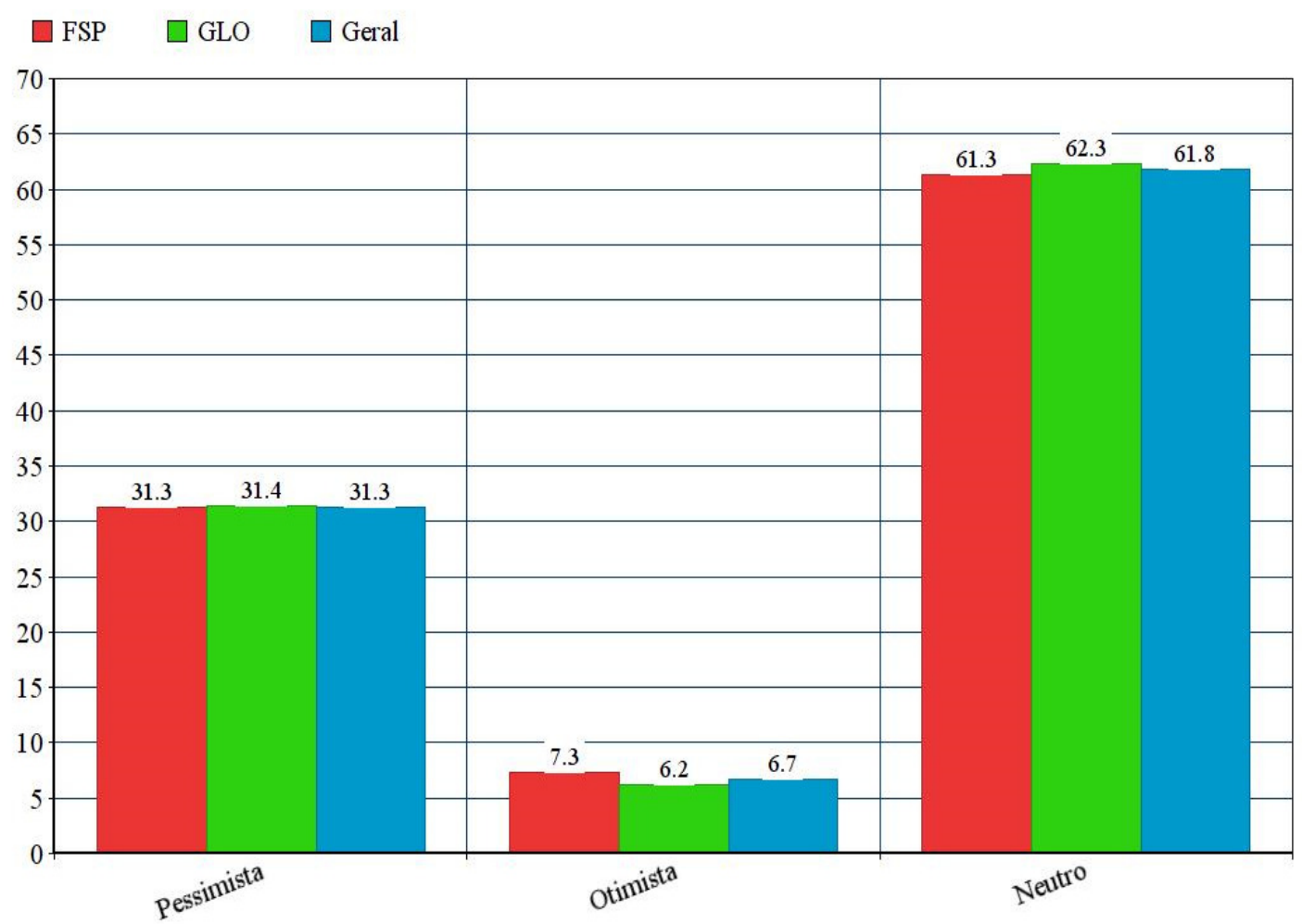

Fonte: COMPA/UFPR

Por fim, para definição do gênero narrativo, a última variável tratou dos resultados esperados. Havia três possibilidades para os textos: não haver resultado a ser alcançado, o conflito ter sido resolvido e o conflito não ter sido solucionado.

O mais recorrente foi que os textos não fossem escritos em termos de resultados a serem esperados a partir das situações retratadas (458 notícias). A matéria "Os homens de Temer" (GLO, 12/05/16) apenas apontava quais eram os principais aliados do então vicepresidente, sem que houvesse alguma questão a ser resolvida.

Em seguida, com uma diferença pequena em número de textos, estavam as matérias em que o conflito não foi resolvido. Na notícia "Relator tem cargos no governo e diz que não os entrega" (FSP, 22/03/16), a disputa entre o deputado federal Jovair Arantes (PTB) e o governo se mantém aberta, uma vez que não é relatada a solução do conflito que é central para a matéria. 
Os textos em que houve a resolução do conflito representam apenas 416 do total. A cada etapa do processo de impeachment que era concluída, eram comuns textos que se enquadrassem nessa categoria. É o caso da aprovação na Comissão Especial do Impeachment na Câmara, que representou uma primeira conclusão no longo procedimento para a destituição ("Por 38 a 27, comissão aprova relatório pró-impeachment”, FSP, 12/04/16). O gráfico 4, abaixo, contém todos os dados dessa variável.

Gráfico 4 - Resultados esperados

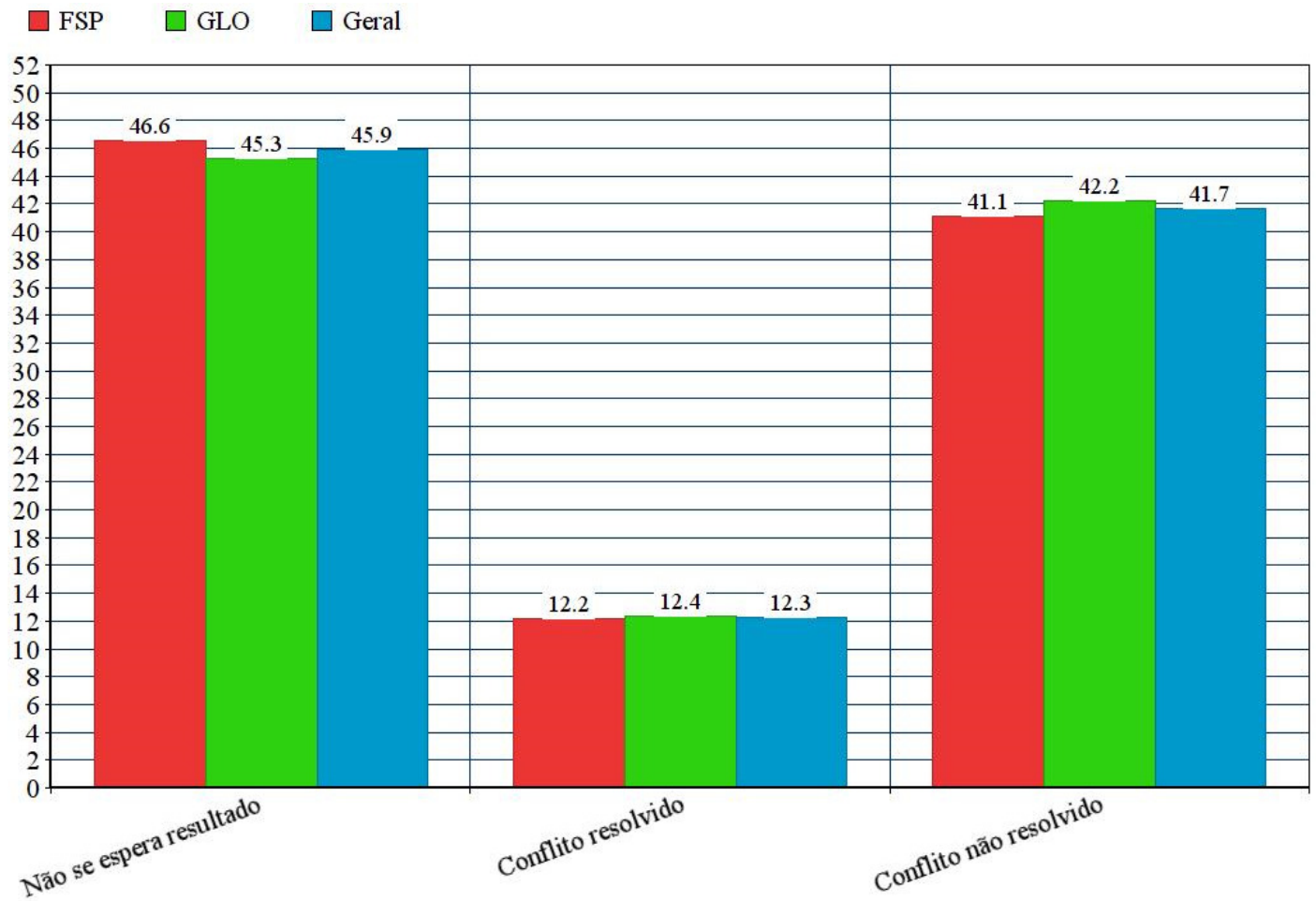

Fonte: COMPA/UFPR

Relacionando as variáveis analisadas nesse subconjunto do gênero narrativo, é possível observar características dessa cobertura, especialmente no que diz respeito às correspondências entre o tema geral da notícia e o tom adotado pelo texto. O gráfico 5 apresenta a recorrência dos temas, sendo que cada tema está subdividido pelo tom correspondente, a fim de observar as divisões internas. 


\section{Gráfico 5 - Relação entre Tom e Tema Geral}

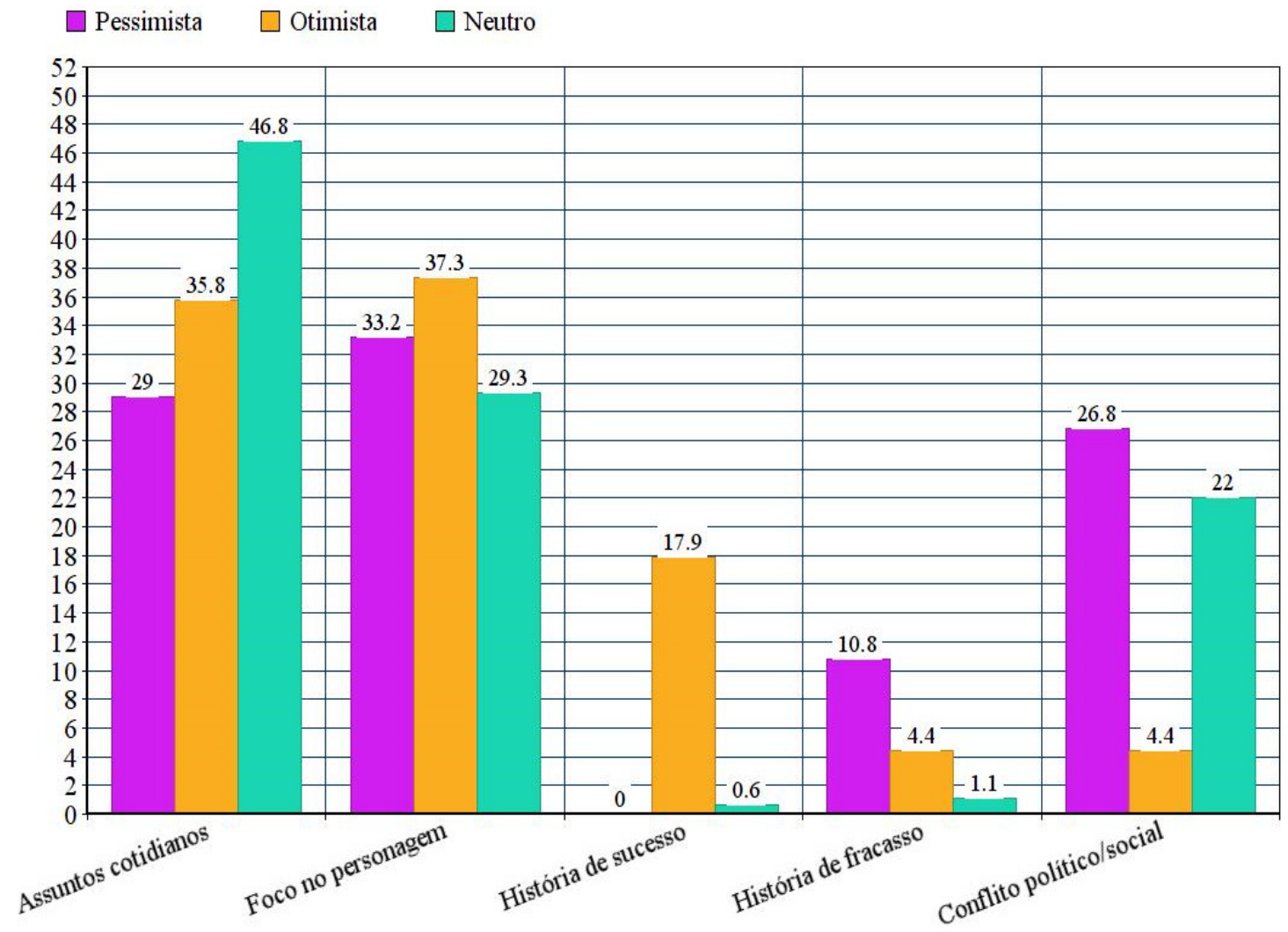

Fonte: COMPA/UFPR

Como esperado, dentre os textos identificados como histórias de sucesso, o tom otimista foi majoritário, estando presente em quase todas as notícias dessa categoria. Essa angulação otimista também foi a mais recorrente nas matérias de foco no personagem, ainda que com pouca diferença para os outros dois tons presentes. O tom neutro foi predominante nas matérias com assuntos cotidianos, o que indica que essa abordagem do processo político a partir de uma visão burocrática e cartorial foi correspondida com um tom que não pendia para visões pessimistas ou otimistas do processo. $\mathrm{O}$ tom pessimista foi predominante em dois temas: nas histórias de fracasso, como já podia ser esperado, mas também nas notícias enquadradas como conflito político/social, o que é um sinal de que as matérias dedicadas aos embates entre os adversários realizavam um julgamento negativo dessa disputa política. 


\section{Identificação dos personagens: herói, vítima e vilão}

Em relação aos papeis atribuídos aos sujeitos das notícias o vilão, foi o personagem mais recorrente (17,5\%), seguido pela vítima (14,1\%) e pelo herói (11,5\%) (Gráfico 6). Ainda que não haja diferença numérica significativa entre os dois jornais, cabe ressaltar que a FSP apresentou números relativos superiores aos do GLO para todos os personagens. Na FSP, 15,1\% das matérias apresentaram uma vítima, ao passo que em GLO o índice foi de 13,3\%. Em relação à incidência do vilão, eles apareceram em 18,2\% das notícias da FSP e em 17\% das notícias do GLO. No caso do herói a diferença percentual é maior entre os jornais - na FSP $13,1 \%$ das reportagens tinha algum herói e no GLO, 10,2\%.

\section{Gráfico 6-Papéis}

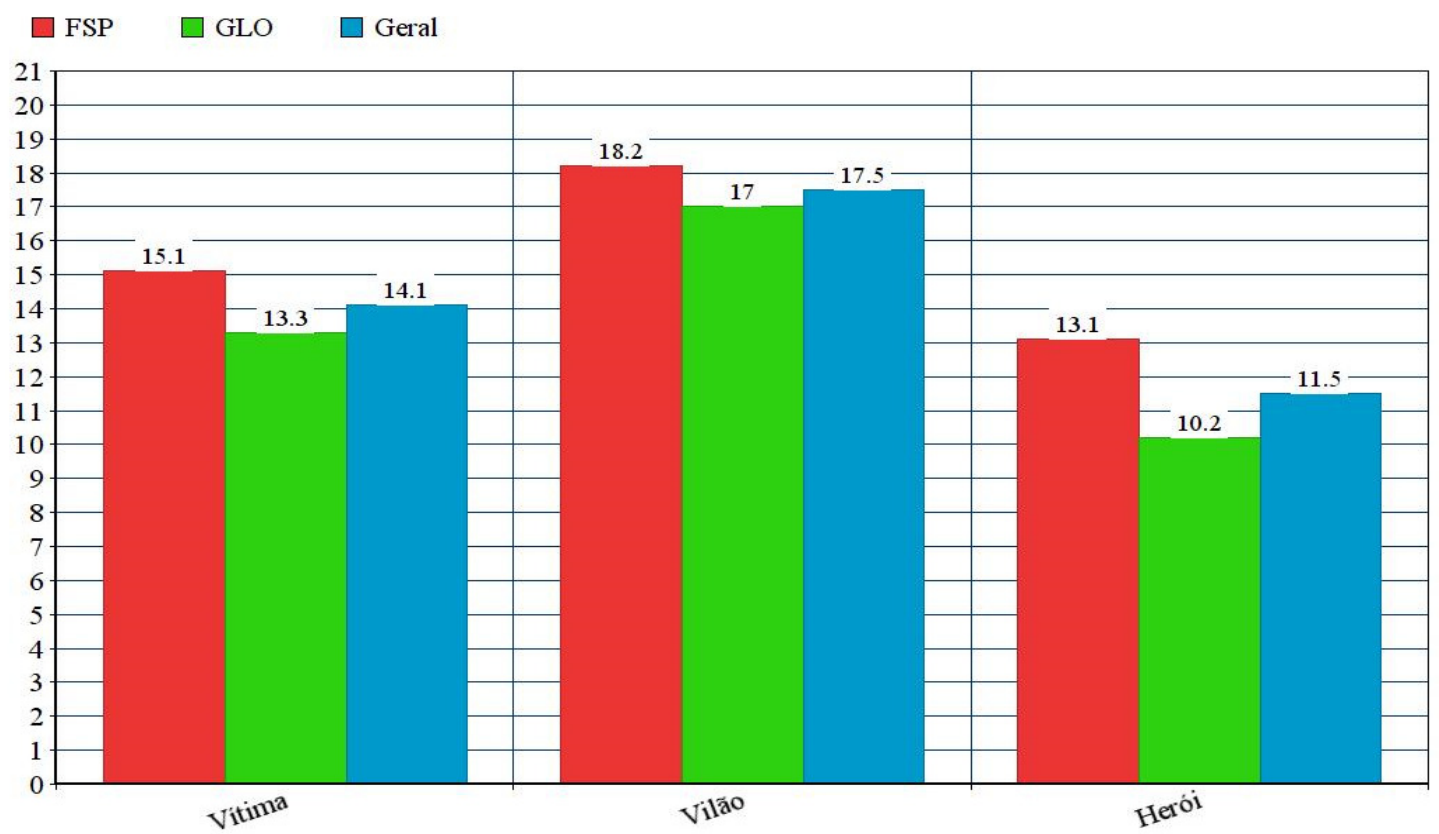

Fonte: COMPA/UFPR

Vale lembrar que, para fins da codificação, o livro de códigos elaborado pelo COMPA determinou que o papel de vítima seria atribuído a uma pessoa, grupo ou instituição que é prejudicada ou sofre. Quando o sujeito precisa ser defendido por outros sujeitos ou age 
defensivamente também se configura como vítima. Foram codificados como vilões qualquer pessoa, grupo, instituição ou "coisa" responsável por problemas específicos, prejuízos ou danos em relação a outros. E o herói é qualquer pessoa, grupo ou instituição admirada por seu sucesso, sua coragem, resultados alcançados ou qualidades nobres. $\mathrm{O}$ herói também aparece quando age para defender uma vítima ou quando "luta" contra o vilão.

\section{Vítima}

Nos dois jornais percebe-se que a então presidenta do Brasil Dilma Rousseff foi, quantitativamente, a vítima mais frequente (Gráfico 7). Na FSP Dilma surge como vítima em 43 oportunidades e em 44 no GLO.

\section{Gráfico 7 - Vítimas}

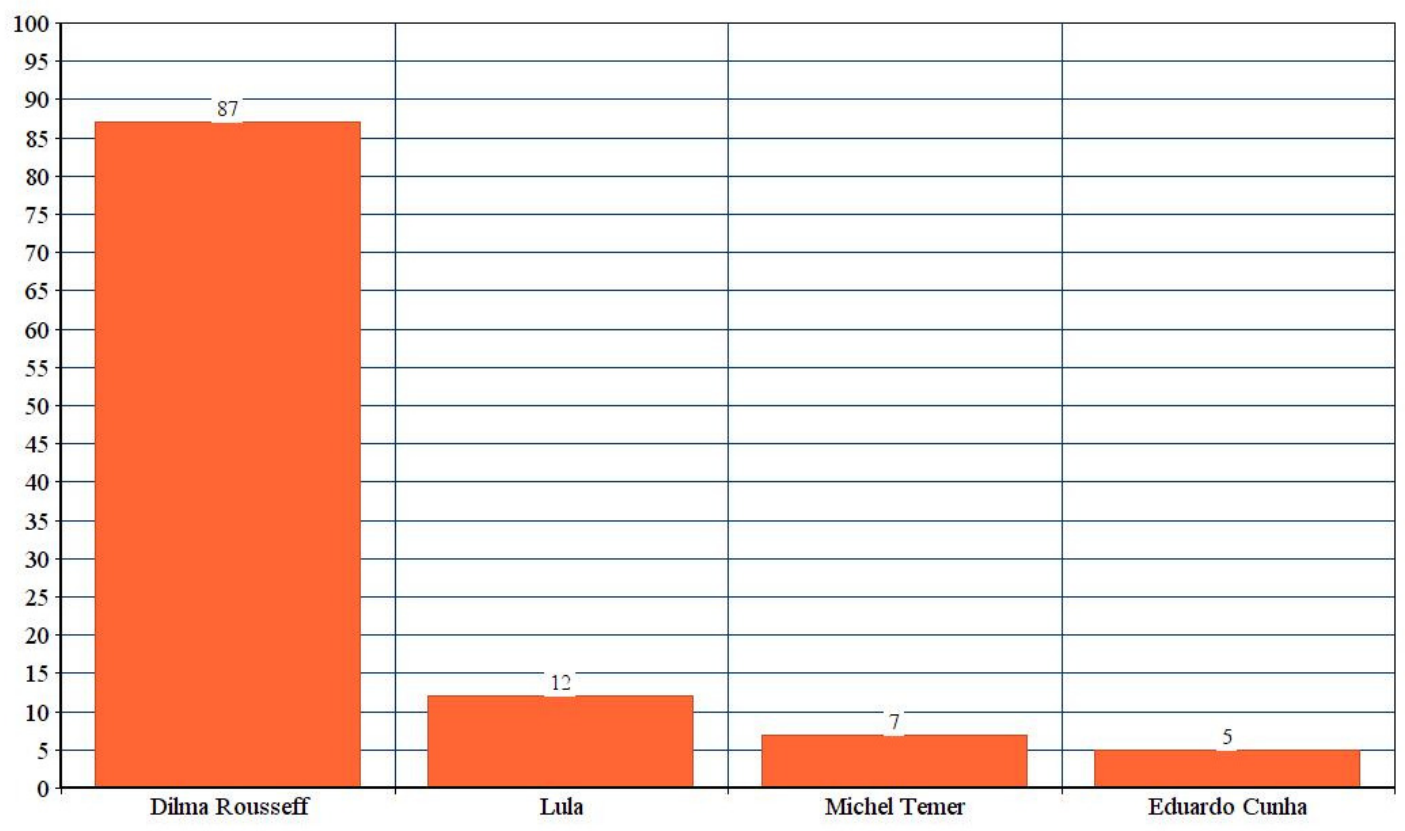

Fonte: COMPA/UFPR

Um dos casos em que Dilma foi identificada como vítima ocorreu na matéria 'Maioria dos governadores é contra o impeachment', publicado pela FSP no dia 07/12/2015. Na ocasião, a então presidenta recebeu apoio de apenas 15 dos 27 governadores. Três dias depois, em 
10/12, a reportagem "Dilma e Temer prometem relação 'profícua"' também vitimizou Dilma. Na oportunidade, o vice-presidente Michel Temer "reafirmou os pontos de insatisfação que estavam na carta enviada por ele no Planalto" divulgada no dia 07. A matéria, contudo, aponta que "longe dos holofotes a situação é menos amigável. O grupo de Temer ameaça antecipar a convenção nacional do PMDB”, partido do vice. O encontro, segundo a matéria, discutiria a ruptura da sigla com o governo de Dilma. Além disso, há a afirmação de que a ex-presidenta ficou "assustada com os termos" da carta divulgada por Temer. Outra notícia que coloca Dilma como vítima é "STF derrota Dilma e rejeita adiar voto do impeachment", publicada pela FSP no dia 15/04/2016. O texto relata que "com os partidos abandonando a base aliada e a pressão cada vez maior pelo impeachment, o governo recorreu ao STF (Supremo Tribunal Federal) para barrar o avanço do processo na Câmara, mas acabou derrotado".

No jornal GLO, a matéria "Isolamento no poder" (09/05/2016) também colocou Dilma no papel de vítima. A reportagem cita a "cara cansada, abatida e triste" da presidenta e ainda salienta que, já nas vésperas da votação do seu impedimento no Senado Federal, ela própria "tem a convicção de que significará seu afastamento da Presidência da República".

No dia seguinte, na reportagem "Defesa de Dilma vai recorrer ao Supremo" o jornal GLO mostrou que, diante da impossibilidade de o processo de impeachment no Senado ser paralisado, a defesa de Dilma iria recorrer da situação no STF. Nesse caso, Dilma foi defendida pelos seus advogados de defesa em um processo que estava em trâmite e que, segundo eles, era injusto. Antes, no dia 04/05, GLO publicou o texto "Algoz de Collor, advogado diz que Dilma não cometeu crime". Nessa reportagem o advogado Marcelo Levenère, que foi o responsável pela denúncia que levou ao impeachment do ex-presidente Fernando Collor em 1992, foi usado como fonte. Segundo a publicação, o advogado ressalta que "no caso do presidente Collor, tinha crime praticado pelo presidente (...). Neste processo de impeachment que estão agora examinando não existe isso. Não há crime nenhum". Nesses dois casos, Dilma precisou ser defendida por terceiros.

Além de Dilma, o ex-presidente Lula também apareceu como vítima em seis reportagens de cada um dos jornais. No dia 15/02/2016, a FSP publicou a matéria "No Rio, Dilma diz que Lula é vítima de grande injustiça", em que Lula é defendido por Dilma: "Respeito muito a história do presidente Lula e tenho certeza de que esse será um processo que será 
superado porque acredito que o país, a América Latina e o mundo precisam de uma liderança com as características do presidente Lula", disse Dilma, segundo a reportagem. No GLO, a matéria "Lulinha paz e amor. De novo", veiculada em 19/03/2016, também retrata Lula como vítima, já que teve sua posse como ministro suspensa pelo Judiciário. Em discurso na Avenida Paulista, em São Paulo, Lula se defendeu e foi defendido por populares. Ele disse "que não há espaço para ódio no país, aconselhando todos a não aceitarem provocações". Além disso, segundo a matéria, "uma multidão de militantes de esquerda (...) atacavam as decisões judiciais contra Lula”.

Já Michel Temer, então vice-presidente do Brasil, foi taxado como vítima quatro vezes pela FSP e três vezes pelo GLO. Um exemplo é a matéria "Vice chama de 'mentira rasteira' acusação de que pretende acabar com Bolsa Família", do dia 17/04/2016. No mesmo dia, a FSP abordou o mesmo assunto na matéria "Temer acusa Dilma de mentir e diz que manterá programas" também tratando Temer como vítima.

Atores institucionais como o governo, partidos e a própria Operação Lava Jato também

foram diagnosticados como vítimas. É exemplo a publicação "Lava Jato reage e vê guerra nas sombras", do dia 18/03/2016, na qual a FSP coloca como vítima a operação Lava Jato. "Em discurso duro em frente à sede da Justiça Federal de Curitiba, o coordenador da forçatarefa da Lava Jato em Curitiba, Deltan Dallagnol, defendeu a operação”. Ainda segundo a matéria, Deltan afirmou que "as tentativas de amedrontar policiais federais, auditores da Receita Federal, procuradores da República e o juiz federal Sergio Moro devem ser repudiadas".

\section{Vilão}

Em relação aos personagens considerados como vilões, isto é, que agiram no sentido de prejudicar outros, Dilma e Cunha são os mais recorrentes (Gráfico 8). Entretanto, nesse caso, houve diferenças significativas entre os dois veículos. Se na FSP Dilma Rousseff surge com o maior número de entradas como vilã (em 15 oportunidades), no GLO é o exdeputado federal Eduardo Cunha que lidera este ranking (24 vezes). Por outro lado, GLO considerou Dilma como vilã em 19 reportagens, já a FSP considerou Cunha como vilão em 12 oportunidades. 


\section{Gráfico 8 - Vilões}

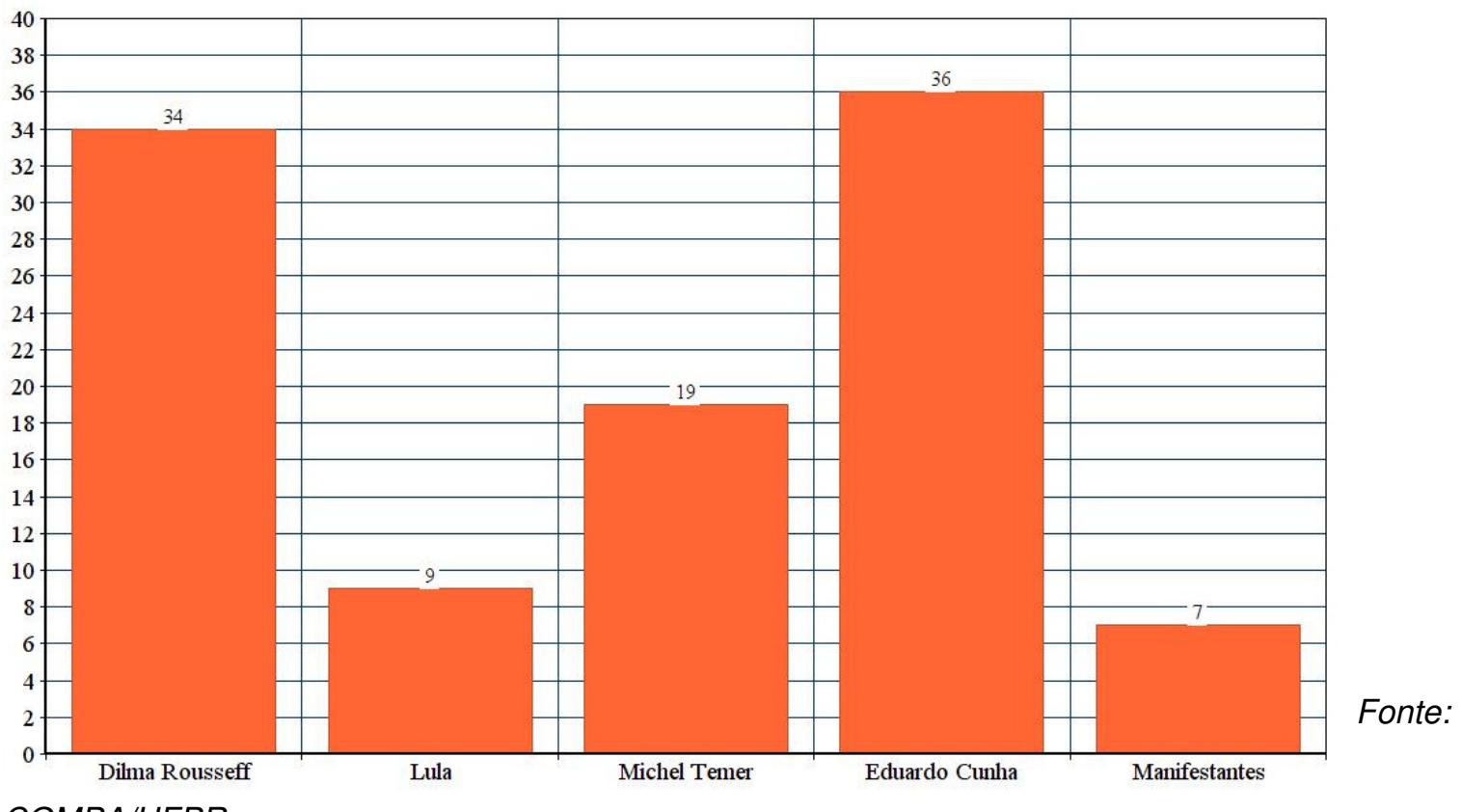

COMPA/UFPR

A FSP tratou Dilma como vilã na notícia "Dilma atuou para tentar evitar prisão de Lula, indica gravação da PF”, que foi publicada na edição do dia 17/03/2016. Esta matéria relata que o juiz federal Sergio Moro incluiu no inquérito que tramita em Curitiba "uma conversa telefônica entre o ex-presidente Lula e a presidenta Dilma Rousseff na qual ela diz que encaminhará a ele o 'termo de posse' de ministro. Dilma diz a Lula que o termo de posse só seria usado "em caso de necessidade"'. Segundo a reportagem, os investigadores da Lava Jato interpretaram o diálogo como uma tentativa de Dilma de evitar uma eventual prisão de Lula. "Se houvesse um mandado do juiz, de acordo com essa interpretação, Lula mostraria o termo de posse como ministro e, em tese ficaria livre da prisão". Este fato denota, portanto, que Dilma estaria agindo - conforme a reportagem - para obstruir ou dificultar a ação do Poder Judiciário.

Outra matéria da FSP que mostra Dilma como vilã é a "7 pecados na capital", do dia 17/04, que diz que a ex-presidenta não teve competência para evitar o impeachment: "A Folha elencou sete aspectos que levaram o governo petista à lona, correlacionados com os pecados mortais dos quais mais se aproximam. Acima de todos eles está a soberba, que 
permeia os demais. O temperamento difícil e a falta de urbanidade política de Dilma cobraram um preço alto ao fim”, diz trecho da notícia.

Ainda em relação à Dilma, o jornal GLO a tratou como vilã na notícia "Relator refuta 'golpe' e pede saída de Dilma”, publicada em 05/05/2016. "O Relator do pedido de impeachment, senador Antonio Anastasia (PSDB-MG), apresentou nesta quarta-feira um parecer favorável à abertura do processo contra a presidenta Dilma Rousseff, como esperado, desclassificando as alegações de que o processo se trata de um golpe", diz trecho da reportagem, que ainda publicou frases de Anastasia colocando a culpa pela situação e por atos considerados criminosos na própria Dilma. "Consideramos que os fatos criminosos estão devidamente descritos, com indícios suficientes de autoria e materialidade, há plausibilidade na denúncia e atendimento aos pressupostos formais, restando, portanto, atendidos os requisitos exigidos pela lei para a denunciada responda ao processo de impeachment", afirmou o senador em trecho destacado pelo jornal.

Outro protagonista que teve grande incidência no papel de "vilão" foi o ex-deputado estadual Eduardo Cunha. É exemplo a notícia "Cunha ameaça impeachment, e petistas discutem salvá-lo", veiculada pela FSP no dia 01/12/2015. Esta matéria mostrou o lado de barganha e chantagem de Cunha, que era presidente da Câmara dos Deputados. A matéria mostra que Eduardo Cunha ameaçou deflagrar processo de impeachment "contra a presidente Dilma Rousseff caso o PT não ajude a salvar o mandato dele", que estava sendo julgado por quebra de decoro parlamentar no Conselho de Ética. A matéria ainda completa: "a ameaça de Cunha de dar seguimento ao impeachment foi feita em almoço com o vicepresidente, Michel Temer, quando, segundo a Folha apurou, ele disse que iria esperar o comportamento dos três deputados petistas no Conselho de Ética para só então decidir o que fará com os pedidos de impeachment”. Depois que os membros do PT afirmaram que não iriam votar a favor de Cunha, este abriu o processo de impeachment contra Dilma.

No GLO, um exemplo de abordagem que vilanizou Eduardo Cunha apareceu no dia 16/12 (“Cunha é alvo por suspeitas de achaques e venda de Mps”), quando o ex-deputado foi considerado vilão por ter sido alvo de uma operação da Policia Federal. 
Com Cunha, a Polícia Federal apreendeu três celulares, um laptop, pelo menos um computador e sacolas de documentos. Estão em apuração suspeitas de achaques, supostas tentativas de vender trechos de medidas provisórias, aprovações suspeitas de projetos de lei, além de atuações para atrapalhar investigações criminais e administrativas. (O Globo, 20154).

Lula e Michel Temer também foram retratados como vilões pelos dois jornais. Lula foi vilão em cinco notícias da FSP e em quatro do GLO. Temer, vilão mais frequente que Lula, foi assim representado em nove textos da FSP e em 10 do GLO.

Um exemplo é a matéria da FSP, "Procuradoria denuncia Lula e pede inquérito sobre Dilma", do dia 04/05/2016, que aborda o pedido de abertura de inquérito para investigar a presidenta Dilma Rousseff, o ex-presidente Luiz Inácio Lula da Silva e o ministro José Eduardo Cardozo (Advocacia-Geral da União) por suspeita de obstrução da Lava Jato, acusando Lula de prejudicar ações da Justiça e de ter cometido crimes que prejudicaram a sociedade em geral. A indicação de Lula à Casa Civil, segundo a reportagem, fez parte das ações que visavam "evitar que ele fosse investigado pelo juiz Sérgio Moro, pois ganharia foro especial e seu processo iria para o STF".

No GLO Lula também surge como vilão em situações semelhantes, como pode ser denotado na reportagem publicada no dia 04/05/2016 intitulada "Organização criminosa não funcionaria sem Lula", que da mesma forma que a matéria citada acima, aponta o expresidente como o responsável pelos crimes de corrupção.

Já Michel Temer foi apontado como vilão, por exemplo, na matéria da FSP "Atual vice chancelou polêmica importação de equipamentos em 91", do dia 10/05/2016, que afirma que Temer agiu ilicitamente quando foi procurador-geral do Estado de São Paulo no governo de Luiz Antônio Fleury Filho (1991-94):

O vice-presidente Michel Temer teve sua passagem pelo cargo marcada por uma polêmica: a importação de equipamentos eletrônicos israelenses, com acusação de superfaturamento. A legalidade da operação havia sido questionada pelo exsenador Severo Gomes (PMDB), então secretário de Ciência e Tecnologia. (Folha de S. Paulo, 2016 ${ }^{5}$ ).

4 "Cunha é alvo por suspeitas de achaques e venda de Mps". O Globo, 16/12/2015.

5 Atual vice chancelou polêmica importação de equipamentos em 91equipamentos. Folha de S. Paulo. 10/05/2016. 
A diferença de abordagem dos dois veículos é novamente percebida quando se trata dos manifestantes. Na FSP apenas uma vez quem foi às ruas contra o impeachment de Dilma recebeu o tratamento de vilão ("Protestos pró-Dilma são ato de guerrilha, diz Moraes", do dia 11/05). No GLO, por outro lado, os manifestantes foram vilões em seis oportunidades, sendo que em duas delas eram favoráveis ao impedimento de Dilma e nas demais eram contrários ao processo.

\section{Herói}

Por fim, o Gráfico 9 mostra que como heróis, que lutam para defender a si ou a eventuais vítimas, aparecem mais frequentemente os manifestantes - tanto favoráveis (16 vezes) quanto contrários (12 vezes) ao impeachment. Dilma aparece como heroína em dez notícias, sendo seis na FSP e quatro no GLO. Lula, oito vezes na FSP e três vezes no GLO. Michel Temer foi retratado como herói sete vezes, todas elas pelo jornal GLO. Era esperado que Sérgio Moro figurasse nessa lista, porém, surpreende que ele tenha aparecido somente cinco vezes como herói, mesmo número que Eduardo Cunha.

\section{Gráfico 9 - Heróis}

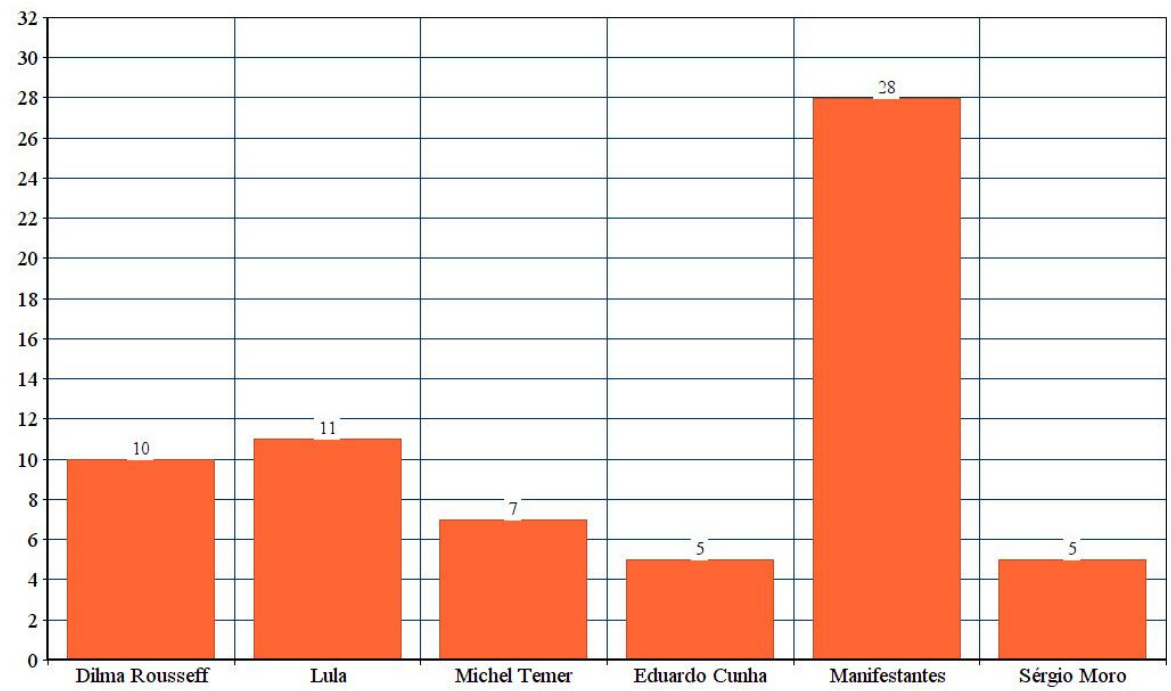

Fonte: $C O M P A / U F P R$ 
Heróis bastante frequentes, os manifestantes pró-impeachment foram identificados nesse papel por estarem agindo em torno de um ideal e defendendo tal posicionamento, como nas matérias do GLO "Em SP, 30 mil vão à Av. Paulista" (14/12/2015), "A festa dos próimpeachment" (03/12/2015) e "Protestos e panelaços ocupam as ruas" (17/03/2016), e nas da FSP "Pegos de surpresa, grupos anti-Dilma voltam às ruas" (13/12/2015), "Manifestantes a favor de Dilma fecham Avenida Paulista em SP" (13/05/2016), "Grupo pró-impeachment volta à Av. Paulista" (20/03/2016) e "Resultado da votação é recebido com buzinaço e choro na Paulista", (18/04/2016), da qual destaca-se o trecho: "Entre os que vibravam, alguns choraram, e muitos gritavam 'fora, $\mathrm{PT}^{\text {' }}$ assim que o último voto 'sim' foi declarado. Até a batucada parecia com uma torcida organizada. No samba a favor do impeachment, tinha caixa, surdo e tamborim".

Os manifestantes contrários ao impeachment também foram classificados como heróis pelas mesmas razões, como pode ser observado nas seguintes matérias da FSP: "Manifestantes pró-governo vão às ruas" (16/04/2016) e "Universidade de Moro vira palco de ato a favor de Lula" (23/03/2016). No GLO, quem lutou contra o impedimento de Dilma também foi tratado como herói em situações parecidas. Algumas matérias em que esse papel pode ser observado são "Ocupa Palácio: Salão nobre ganha 'acampamento" (10/05/2016), "Protestos contra impeachment" (25/03/2016) e "Protestos a favor de Dilma ocorrem em 25 estados" (17/12/2015).

Michel Temer, que figura como líder de incidências como "herói” no GLO, aparece neste jornal como aquele que luta e age em defesa da sociedade em matérias como: "Temer agora propõe a adoção do semiparlamentarismo no país" (12/12/2015) e "Ao pé do ouvido" (13/12/2015), que narra os bastidores das negociações acerca de um eventual futuro governo. O texto enaltece que Temer iria fazer cumprir os acordos, ao contrário de sua antecessora: "Os principais argumentos usados são os estilos diferentes de Dilma e Temer na convivência política; a ampliação de espaços no governo, e a garantia de que os compromissos assumidos serão cumpridos".

A ex-presidenta Dilma figura como heroína especialmente quando age para salvar seu mandato, como é exemplo a matéria do GLO, do dia 15/04, que levou o título "Dilma convoca governadores do NE para tentar conter debandada". Lula aparece como herói em 
três oportunidades no GLO e em oito na FSP. A maioria delas relata as ações realizadas por ele para defender Dilma, como é o caso da notícia do GLO "Lula lidera força tarefa pela permanência de Dilma” (29/03/2016).

\section{Discussão dos resultados}

A análise de narrativa desenvolvida neste artigo permitiu vislumbrar certos aspectos da cobertura jornalística do processo do impeachment ocorrido entre 2015 e 2016, que serão melhor desenvolvidos a seguir. No aspecto da dramatização, presente em quase um terço dos textos, o esforço jornalístico em oferecer matérias que não seguissem a construção jornalística tradicional pode ser interpretado como uma tentativa de chamar a atenção do leitor para o tema do impeachment, que era exclusivo do caderno de política e carrega uma seriedade com ele. A tentativa de criar alguma identificação com um processo burocrático parece ser a motivadora da utilização da ferramenta da dramatização (Neves, 2005; Sousa, 2005), buscando contar histórias em vez de apenas apresentar lead, sublead e correlatas. Consegue-se, assim, colocar em ordens todos os elementos do processo e facilitar o entendimento (Prior, 2018). A abertura do processo pelo presidente da Câmara, a passagem pela comissão e a consequente votação pelo plenário da Câmara são apresentadas como início e fim de um drama, de modo a aumentar a repercussão dos acontecimentos.

Já o elemento da personalização, que dominou metade das matérias analisadas, é característica recorrente da cobertura jornalística (Echeverria, 2017) e não foi diferente na cobertura dos dois jornais aqui analisados. Mais uma vez, a tentativa de simplificar os acontecimentos leva os textos a se concentrarem em um agente, que por repetição torna-se o personagem principal dessa história conhecida como o processo de impeachment. Deputados e senadores do governo e da oposição foram escolhidos para sumarizar os acontecimentos, o que transformou uma disputa política que envolve ao menos 513 deputados e 81 senadores em brigas de poucos envolvidos. A complexidade do processo político e do próprio instituto do impeachment ficou resumida aos atos de alguns poucos personagens que, tal como uma narrativa clássica, podiam ocupar algum papel, o que será desenvolvido mais adiante. 
A emoção é elemento que ocupou papel de destaque nessa construção narrativa levada a cabo ao longo da cobertura do impeachment. Com uso de verbos mais sofisticados que apenas dizer ou declarar, o jornalismo é capaz de construir representações vívidas dos acontecimentos e permite a dramatização dos eventos. Assim, descrever lamentos e euforias, como foi apontado pelos achados da pesquisa, torna sensorial para o leitor a experiência de consumir o texto jornalístico e aumenta o próprio engajamento do cidadão com o desenrolar do processo de impedimento.

A questão da ornamentação estilística foi a menos frequente entre as quatro características, até por se chocar com os padrões estabelecidos por praticamente todos os manuais de jornalismo. Como o texto noticioso deve ser entendido pelo público amplo, mesmo a utilização de recursos como a narração e a dramatização não podem vir acompanhados de construções frasais mais complexas que possam dificultar a leitura do texto e afugentar o leitor de alguma forma.

A classificação quanto ao gênero jornalístico demonstrou que a opção por assuntos cotidianos foi a mais frequente, ou seja, matérias que abordavam o assunto de maneira bastante protocolar, indicando que a cobertura jornalística não demonstrou a carga de excepcionalidade que carregava o processo do impeachment (Rizzotto; Prudencio; Sampaio, 2017). A segunda opção mais frequente, contudo, está em sintonia com os resultados já encontrados nas outras categorias, pois correspondeu a textos com focos no personagem. Os recursos de personalização e dramatização são úteis para a escrita de textos desse estilo, que preferem trazer o acontecimento sempre com foco em um indivíduo. Assim, descrever o impeachment a partir das condutas da ex-presidenta Dilma Rousseff presumia tratar as questões políticas por meio de individualizações e com recursos narrativos nem sempre presentes no jornalismo diário.

No que diz respeito aos personagens, os resultados da pesquisa apontam para a maneira ambivalente pela qual a ex-presidenta Dilma Rousseff foi retratada: ora era vítima do processo, ora vilã do cenário. Essa opção pela vilania pode ser encaixada numa tendência já apontada na literatura de que os grandes veículos apresentam uma cobertura negativa em relação aos governos do PT. Nesse caso, a então chefe de Estado era integrante do partido, o que pode ter contribuído para que as matérias construíssem em torno de sua figura uma imagem de vilania. Não é possível ignorar, porém, que ela também foi retratada como 
vítima, o que indica que os textos não adotaram um viés completamente hostil à figura da mandatária. Os mesmos jornais traziam textos com visões diferentes sobre a personagem, o que permite vislumbrar uma heterogeneidade na cobertura: não havia papéis sempre definidos e cada texto apresentava os atores à sua maneira (ou até mesmo não apresentavam personagens sob esse rótulo, como a pesquisa demonstrou).

A cobertura jornalística dos eventos aqui retratados pode apontar, especialmente na questão do vilão, para um fenômeno de naturalização do personagem (Reis, 2006), tendo em vista que foi o mais recorrente. Em outras palavras, certos atores políticos foram retratados sempre sob a ótica com a qual o público leitor já se acostumou a se deparar. O ex-presidente da Câmara Eduardo Cunha é o exemplo mais nítido disso, pois apareceu com enorme frequência nessa categoria, o que pode induzir o público a sempre esperar que sua aparição no âmbito noticioso seja sob esse ângulo.

Por fim, o aspecto do heroísmo foi ressaltado ao longo dos textos, em primeiro lugar, para os manifestantes, ou seja, não ficou restrito a poucos indivíduos que já detivessem alta carga de visibilidade. A tendência, assim, é que o jornalismo buscasse envolver o leitor no processo, ao mostrar que o cidadão comum possuía características positivas e agia de maneira a movimentar a história conforme os heróis dos textos literários. Colocar figuras com que o leitor pudesse se identificar como os benfeitores da trama foi uma tática, ao lado de outras já mencionadas no trabalho, para capturar a atenção do público leitor.

\section{Considerações finais}

A cobertura noticiosa de um acontecimento político dessa magnitude e complexidade demanda dos jornais estratégias narrativas que objetivam oferecer imagens simbólicas e exemplos com os quais o público possa se identificar, simplificando os meandros da política. Por outro lado, os jornais não podem renunciar aos valores jornalísticos, sob pena de perder credibilidade perante o público - é por isso que a maior parte das notícias apresenta um tom neutro $(61,8 \%)$. Isso explica o que foi constatado pelos dados coletados acerca do grau de narratividade dos jornais: baixa ornamentação estilística (16,8\%), porém presente, provavelmente guiada pelo propósito de sedução do público leitor; média 
dramatização e emoção (ambas com 31,6\%) e alta personalização (50,8\%). Entendemos esses números como significativos, pois embora representem apenas cerca de um terço das notícias no caso da dramatização e da emoção e pouco mais da metade no caso da personalização, eles destoam das características informativas clássicas do jornalismo. Talvez isso se deva justamente ao fato de se estar lidando com um acontecimento político disruptivo. Tais achados convergem com descobertas já expostas pela literatura (Fernandes; Chagas, 2016), que já haviam apontado os elementos de dramatização desse caso em produtos da imprensa comercial.

Por outro lado, o impeachment foi noticiado na maior parte das vezes em termos de assuntos cotidianos (40,5\%), com alta incidência de foco nos personagens políticos (31\%) e nos conflitos polarizados (22,3\%), definindo, assim, a política em termos de uma luta do bem contra o mal, realizada em espaços institucionalizados e por agentes formais. Ao distanciar a política da rotina dos cidadãos, acaba por gerar uma visão negativa dela, que pode vir a constituir uma sociedade antipolítica, porque contrária a ela, e despolitizada, porque apartada dela (Rizzotto; Prudencio; Sampaio, 2017).

No que diz respeito aos personagens dessa história, Dilma Rousseff foi apresentada como vítima do processo, porém diretamente responsável pela sua derrocada, já que também aparece como uma das vilãs mais frequentes, ao lado do "arqui-inimigo" Eduardo Cunha. Narrativa de poucos heróis, é a própria sociedade, através das manifestações, que aparece nesse papel com mais frequência, mostrando que no conflito entre os do "lado de lá", "nós" somos o lado do bem.

Para a metodologia de enquadramento multimodal, todavia, a análise isolada da narrativa diz pouco acerca da imagem geral construída pelos jornais. É por isso que a pesquisa tem como próximos passos, além da ampliação do corpus incluindo a cobertura da tramitação do processo no Senado, unir os três níveis de análise, pois é a combinação da construção narrativa com as imagens - e sua representação de ícones familiares - e com o enquadramento noticioso que mais pode aproximar a visão do pesquisador da experiência real do público. 


\section{Referências}

ALDÉ, A.; MENDES, G.; FIGUEIREDO, M. Imprensa e eleições presidenciais: Natureza e Consequências da cobertura das eleições de 2002 e 2006. In: LIMA, V. A. (org.). A mídia nas eleições de 2006. São Paulo: Editora Perseu Abramo, 2007

CORREIA, Eduardo Luiz. O "jornalismo de guerra" na configuração da narrativa do noticiário em tempos de impeachment. REU - Revista de Estudos Universitários, vol. 43, n. 1, 2017.

COSTA, Carolina; FERNANDES, Mario. Narrativa jornalística sul-mato-grossense: a reocupação das fazendas pelos índios Guarani Kaiowá no município de Antônio João. Revista Observatório, Palmas, v.4, n.3, p. 811-835, maio. 2018.

ECHEVERRIA, Martin. Personalización política e infoentretenimiento periodístico: Un estudio desde los encuadres. Cuadernos. Info, no 41, 2017,.

FERES JÚNIOR, J.; SASSARA, L. O cão que nem sempre late: o Grupo Globo e a cobertura das eleições presidenciais de 2014 e 1998. Revista Compolítica, v. 6, n. 1, 2016.

FERNANDES, Carla; CHAGAS, Genira. A dramaticidade na narrativa do impeachment de Dilma Rousseff (PT) no Jornal Nacional. Culturas midiáticas, v. 9, n. 2, 2016.

GOMES, Wilson. Publicidade, discutibilidade, visibilidade: Para uma revisão do conceito de esfera pública política. Compós, 16, 2007, Curitiba. Anais...

GUAZINA, L.; SANTOS, E. O impeachment de Dilma Rousseff nas capas da Folha de S. Paulo. Trabalho apresentado no 41ํ Encontro Anual da Anpocs, Caxambu, 2017. Anais...

GUNTHER, A. C. Biased Press or Biased Public? Attitudes Toward Media Coverage of Social Groups. Public Opinion Quarterly, v. 56, n. 2, p. 147, jan. 1992.

KABUENGE, Nathan; COSTA, Alda; FERREIRA JUNIOR, Sergio. A neofeudalização da política mediatizada e a construção narrativa sobre a corrupção no Brasil. Estudos em Comunicação, v. 2, n. 26, 2018.

LIMA, L. A.; SIMOES, P. G. A construção da imagem pública de Dilma Rousseff durante o impeachment: uma análise preliminar. Trabalho apresentado no 41ํㅡㄹ Encontro Anual da Anpocs, Caxambu, 2017. Anais...

MAGNO, Ana Beatriz. O Jornalismo Nos Tempos Da Reportagem: Uma análise da obra jornalística de Ernest Hemingway \& Gabriel García Márquez. 2014. 441 f. Tese (Doutorado em Comunicação) -Universidade de Brasília, Brasília.

MARQUES, F.; MONT'ALVERNE, C.; MITOZO, I. 'Nem Dilma nem Temer': Um estudo quantitativo sobre padrões de cobertura do impeachment de Dilma Rousseff em editoriais jornalísticos. In: NAPOLITANO, J.; VICENTE, M., SOARES, M. (Org.). Comunicação e Cidadania Política. 1ed.Bauru: Editoria da UNESP, 2017, v. 1, p. 101-126. 
MESQUITA, M, A personagem jornalística, As Ciências da Comunicação na Viragem do Século, Comunicação e Linguagens, Lisboa Veja, 2002.

MOTTA, L. G.. A análise pragmática da narrativa jornalística. XXVIII Congresso Brasileiro de Ciências da Comunicação. 2005. Anais...

; GUAZINA, L. O Conflito como Categoria Estruturante da Narrativa Política: o caso do Jornal Nacional. Brazilian Journalism Research, vol. 6, n. 1, 2010.

MIGUEL, L.F.; COUTINHO, A.A. A crise e suas fronteiras: oito meses de" mensalão" nos editoriais dos jornais. Opinião pública, v. 13, n. 1, p. 97-123, 2007.

MUNDIM, P. Cobertura da imprensa e eleições presidenciais de 2006: Efeitos realmente limitados? Revista Brasileira de Ciências Sociais, v. 29, n. 86, 2012.

NEVES, Teresa Cristina da Costa. A dramatização no telejornalismo. Caligrama, v.1, n.3, 2005.

PRIOR, H.; GUAZINA, L.; ARAÚJO, B. Corrupção e escândalo político: o enquadramento dos escândalos Face Oculta e Mensalão na imprensa portuguesa e brasileira. Media \& Jornalismo, v. 14, n. 26, p.167-185. 2015.

PRIOR, Helder. Escândalo Político e Narratologia: tecendo os fios narrativos dos casos Face Oculta e Lava Jato. Revista Famecos, v. 25, n. 1, 2018.

REIS, Carlos. Narratologia(s) e teoria da personagem. Revista do Programa de Pós-Graduação em Letras da Universidade de Passo Fundo, v. 2, n. 1, p. 26-36, jan./jun. 2006.

RIZZOTTO, C. C. PRUDENCIO, K. SAMPAIO, R. C. Tudo normal: a despolitização no enquadramento multimodal da cobertura do impeachment de Dilma Rousseff. Comunicação \& Sociedade, v. 39, n. 3, 2017.

SHUEN, Li-Chang. O Governo, a Imprensa e a Narrativa: Um Estudo sobre o Adversarial Journalism nas capas de O Globo e Folha de S. Paulo Durante a Crise do Governo Dilma. Anais do 40ํㅡㄹ Congresso Brasileiro de Ciências da Comunicação, Curitiba, 2017.

SILVA, Vinicius; MOTA, Célia Maria. Narrativas de identidades no conflito israello-palestino experiências de palestinidade em Joe Sacco. Revista Fronteiras (Online), v. 19, p. 301-312, 2017.

SOUSA, Pedro Diniz de. O discurso dramático da nova imprensa partidária. Anais do 4ํㅗㅇ Sopom, 2005.

TEIXEIRA, Antonio. Modos narrativos de fazer mundos: jornalismo, ficção e verdade. Revista Famecos, vol. 23, n. 3, 2016.

WOZNIAK, A.; LÜCK, J.; WESSLER, H. Frames, Stories, and Images: The Advantages of a Multimodal Approach in Comparative Media Content Research on Climate Change. Environmental Communication, Dec. 2014. 


\section{Os autores}

Carla Rizzotto é doutora em Comunicação. Professora do Departamento de Comunicação e do Programa de Pós-Graduação em Comunicação da Universidade Federal do Paraná. Pesquisadora do Grupo de Pesquisa Comunicação e Participação Política (COMPA). carlarizzotto@yahoo.com.br

Daniela Drummond é doutoranda e mestre em Ciência Política pela Universidade Federal do Paraná (UFPR), Pesquisadora dos Grupos de Pesquisa Comunicação e Participação Política (COMPA) e Midiaculturas. Bolsista Capes.

daniela.imprensacwb@gmail.com

Diego Antonelli é mestre em Comunicação pela Universidade Federal do Paraná. Integrante do Grupo de Pesquisa Comunicação e Participação Política (COMPA). Jornalista. jornalista.diegoantonelli@gmail.com

Paulo Ferraciolli é doutorando em Ciência Política e mestre em Comunicação pela Universidade Federal do Paraná (UFPR). Integrante do Grupo de Pesquisa em Comunicação, Política e Tecnologia (PONTE). Bolsista Capes.

ferracioli.paulo@gmail.com 